Ann. Biol. anim. Bioch. Biophys., 1978, 18 (4), 943-948.

\title{
The spermiation period in the rainbow trout (Salmo gairdneri). Plasma gonadotropin and androgen levels, sperm production and biochemical changes in the seminal fluid
}

\author{
par M. SANCHEZ-RODRIGUEZ, Anne-Marie ESCAFFRE, Sylviane MARLOT, \\ Pierrette REINAUD \\ Laboratoire de Physiologie des Poissons, I. N. R. A., \\ 78350 jouy en josas, France.
}

\begin{abstract}
Summary. Plasma immunoreactive t-GTH and androgens, sperm production and biochemical changes in seminal fluid were studied during the spermiation period in rainbow trout. The volume of sperm collected by hand-stripping was very low $(<0.1 \mathrm{ml})$ at the onset of spermiation, increased slowly during the next 4 weeks and sharply thereafter. Plasma t-GTH was high $(6 \mathrm{ng} / \mathrm{ml})$ at the onset and then decreased; the sharp rise in sperm production started when circulating androgens had reached maximum values. In a second phase (6-12 weeks), the elevation in sperm production was strongly correlated wth plasma t-GTH, while plasma androgens fluctuated. Spermatocrit did not vary significantly during the period studied so that increased sperm production corresponded to an elevation in spermatozoal production. During spermiation $\mathrm{Na}^{+}$ionic concentration in the seminal fluid increased sharply and that of $\mathrm{K}^{+}$only slightly. Total protein in the seminal fluid decreased significantly after 8 weeks.
\end{abstract}

\section{Introduction.}

There is little information in the literature on spermiation in fish, and especially on hormonal control as related to the biochemical composition and quantitative production of sperm. In the present work, we have studied variations of plasma gonadotropin (GTH) and androgens as well as differences in some seminal fluid parameters, such as spermatocrit and protein and mineral concentration, which could serve as sperm quality criteria during spermiation in rainbow trout.

\section{Material and methods.}

Experimental procedure. - Three-year old males weighing $875 \pm 75 \mathrm{~g}$ were purchased from a commercial hatchery and kept in a recycled, bacteria-filtered water system from September until February under seasonal photoperiod and temperature ranging between 8 and $12^{\circ} \mathrm{C}$. After a 1-month acclimation to laboratory conditions, the animals were weighed and their blood sampled on 15 October. From this date, 
the fishes were hand-stripped every week to detect the onset of spermiation. Once it was detected, blood and sperm samples were taken on anesthetized fishes (propoxate R7464, Janssen Pharmaceutica, $2 \mathrm{mg} / \mathrm{l}$ ) every 2 weeks for a period of 12 weeks.

Measurements. - Plasma gonadotropin (GTH) levels were measured by a double specific radioimmunoassay (RIA) (Breton ef al., 1975). Plasma androgen levels were determined by a double antibody RIA without chromatography and with a non-specific antibody (gift of Mr. Terqui), mainly binding testosterone (100 p. 100) and 11 Ketotestosterone (110 p. 100) but less androstene-dione (57 p. 100) and 5 $\alpha$-DHT (37 p. 100) ; adrenosterone, $17 \alpha$-hydroxy-20 $\alpha$-dihydroprogesterone and $17 \beta$-estradiol were not bound $(<0.5$ p. 100).

The volume of sperm released was determined by milt-stripping every time the animals were sampled. The spermatocrit was measured only when the volume of stripped sperm was at least $0.5 \mathrm{ml}$. Total protein concentration in the seminal fluid, obtained after $20 \mathrm{~min}$. of centrifugation at $1500 \mathrm{~g}$, was determined using Lowry's

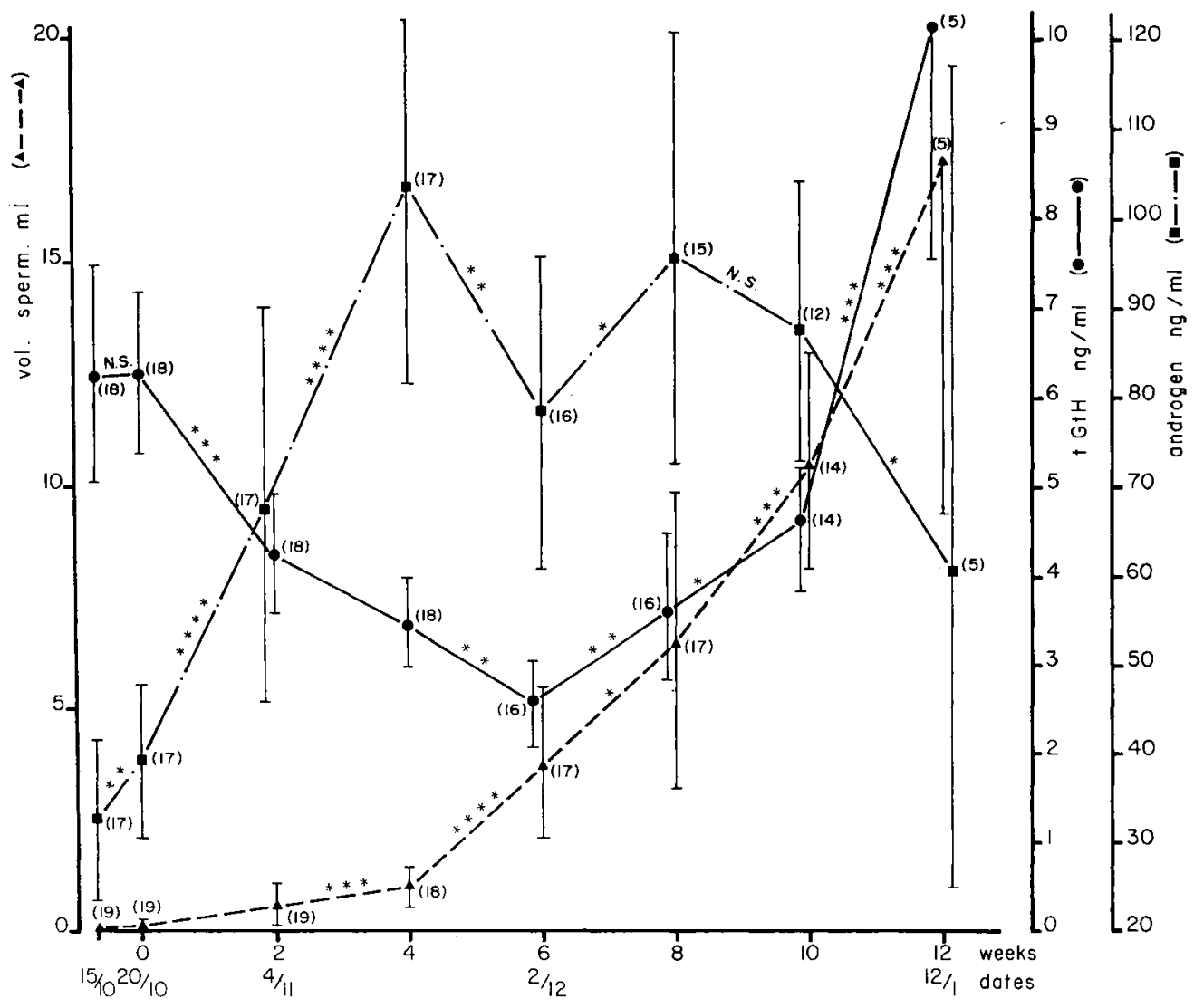

FIG. 1. - Changes in plasma immunoreactive t-GTH, tofol androgen levels and sperm production during the 12 weeks ofter the onsef of spermiation in rainbow trout.

Graphs show the mean value and standard deviation for each parameter. Difference between valu s are expressed as : N.S. : non-significant ; $*: \mathrm{P}<0.1 ; * *: \mathrm{P}<0.05 ; * * *: \mathrm{P}<0.02 ; * * * *$ : $P<0.01 ;(n):$ number of fishes. 
method modified by Hartree (1972) ; sodium and potassium were measured by flame spectrophotometry (Eppendorf model).

The statistical methods used were variance analysis and t-tests; the data were compared with Couple's method.

\section{Results.}

Plasma t-GTH and androgen levels (fig. 1).

Plasma GTH was high at the onset of spermiation $(6.3 \mathrm{ng} / \mathrm{ml})$, decreased during the following 6 weeks, then augmented between weeks 6 and 12, reaching a maximum value at 12 weeks $(10 \mu \mathrm{g} / \mathrm{ml})$. Androgen evolution was the reverse, increasing during 4 weeks from 34 to $104 \mathrm{ng} / \mathrm{ml}$ while $\mathrm{t}-\mathrm{GTH}$ decreased. Total androgen levels then fluctuated, showing a slight decrease.

\section{Sperm analysis.}

The volume of milt produced between 2 samplings increased significantly during the period studied (fig. 1). Sperm production was very low at the onset of spermiation

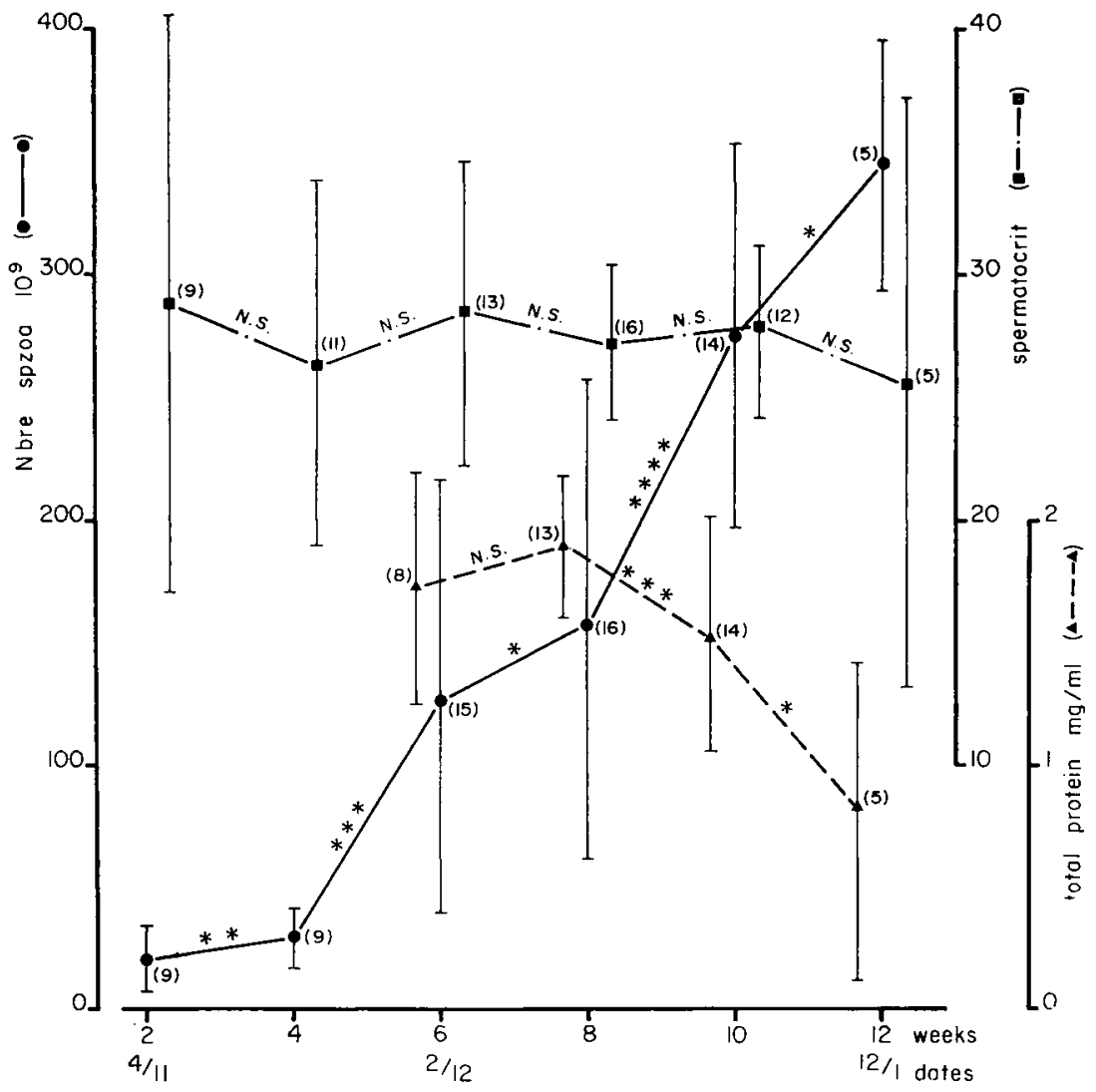

FIG. 2. - Evolution of spermatocrit, number of spermatozoa collected at 2-week intervals, and total protein (ref. albumin) in the seminal fluid during spermiation from weeks 2 to 12. 
$(0.1 \mathrm{ml})$ and rose steadily to reach a maximal value of $17.16 \mathrm{ml}$ at 12 weeks. Spermatocrit did not vary significantly during this period, fluctuating between 28.3 p. 100 at the beginning and 25.4 p. 100 at the end (fig. 2). Spermatozoal production (fig. 2) therefore followed that of sperm (fig. 1).

Total protein. - Seminal fluid protein concentration was at its highest level $(1.74$ to $1.89 \mathrm{mg} / \mathrm{ml})$ at the onset of spermiation. It decreased significantly afterwards and reached a concentration of $0.8 \mathrm{mg} / \mathrm{ml}$ at week 12 (fig. 2).

Sodium and potassium (fig. 3.) - $\mathrm{Na}^{+}$concentration increased steadily from $1.400 \mathrm{mg} / \mathrm{ml}$ at 6 weeks, when first measured, to $2.034 \mathrm{mg} / \mathrm{ml}$ at 12 weeks. Variations in $\mathrm{K}+$ concentration during the same period were different; $\mathrm{K}+$ increased from $784.6 \mathrm{mg}$ $\mathrm{ml}$ at 6 weeks to 1156 at 8 weeks $(P<0.02)$, but decreased to $853.9 \mathrm{mg} / \mathrm{ml}$ at 10 weeks $(P<0.01)$ to increase again at 12 weeks to $1113.6 \mathrm{mg} / \mathrm{ml}(P<0.02)$. The relation $\mathrm{Na}^{+} / \mathrm{K}+$ varied also ; its minimal value was 1.79 and its maximal value 2.36 .

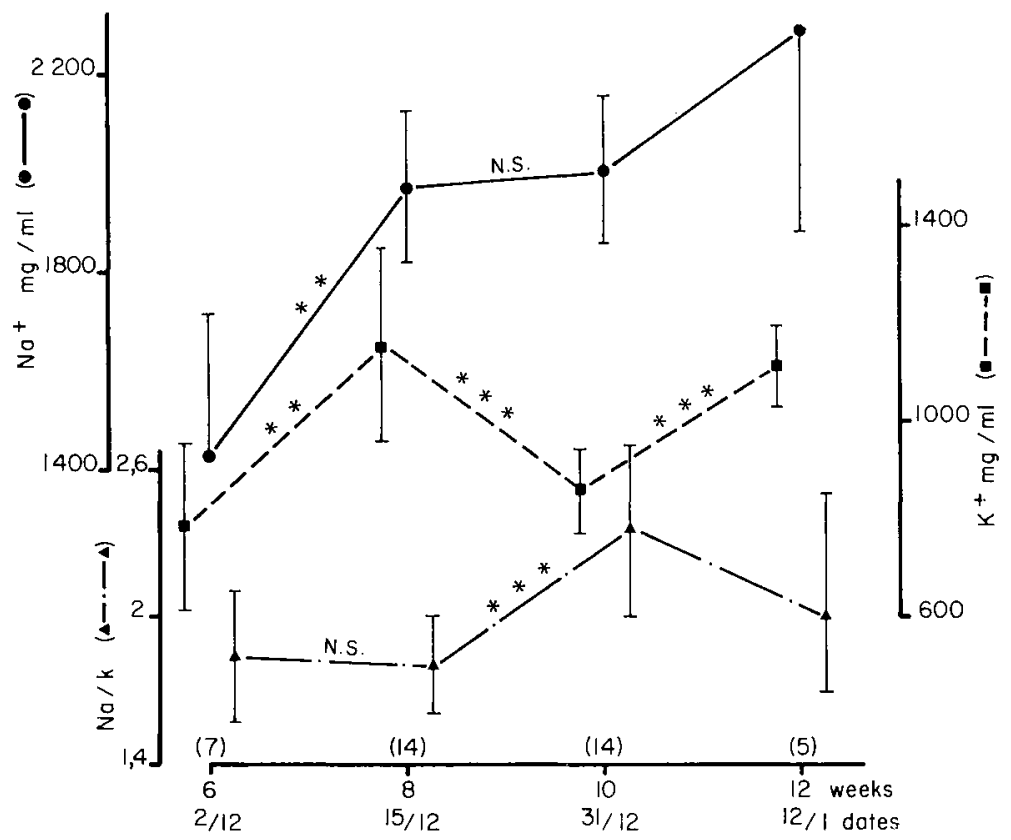

FIG. 3. - Changes in $\mathrm{Na}^{+}$and $\mathrm{K}^{+}$and ratio in the seminal fluid during spermiation in male rainbow trout.

\section{Discussion.}

These data elucidate hormonal changes, sperm production and variation in seminal fluid composition during the 12 weeks following the onset of spermiation. When sperm release is first detected, low amounts of sperm are produced and high levels of t-GTH are recorded in the plasma. Significant sperm production only occurred several weeks later when t-GTH decreased and androgens had reached a maximum level (fig. 1). At the onset of spermiation, the effect of GTH and androgen on sperm 
production were not clear ; GTH might be involved in the initiation of spermiation and the rise of circulating androgens which, in turn, could reduce the t-GTH secretion, thus suggesting a negative androgen feedback on t-GTH. Later, between weeks 6 and 12 , sperm production was more closely correlated with the plasma GTH level. This agrees with data in the literature stating that gonadotropin is involved in sperm release (Clemens and Grant, 1965 ; Yamazaki and Donaldson, 1968). A high level of GTH has also been observed at the end of gametogenesis and during the spawning season in salmonids (Crim, Watts and Evans, 1975; Breton ef al., unpublished data). Plasma androgens reach a maximum value at the same period (Schreck, Lackey and Hopwood, 1972 ; Idler, Horne and Sangalang, 1971). Androgens could also be involved in spermiation, and high levels may be required to stimulate sperm release (fig. 1). Whether only one specific active androgen is involved, or whether there are several, cannot be determined since the antibody used was not specific for any androgen. From the present data two stages are determined during spermiation, (1) initiation and preparatory stage lasting several weeks followed by (2) an active stage of sperm production when androgens are high and GTH is rising. Exogenous androgens alone stimulate spermatogenesis in vivo only when used in very large doses of 100 or $200 \mu \mathrm{g} / \mathrm{g}$ (Billard, 1974). This observation may also apply to spermiation. The spermatocrit stability already reported in this species (Chemayel, 1975) shows that stimulation of sperm production between weeks 6 and 12 is consequently a true stimulation of spermatozoal production.

The drop in seminal fluid protein concentration corresponds to a sharp increase of sperm production, and may suggest that protein synthesis capacity is limited and cannot deal with the copious seminal fluid secretion.

lonic concentration of the seminal fluid is very high and increases mainly in $\mathrm{Na}^{+}$ during the period studied and to a lesser extent in $\mathrm{K}^{+}$. The rise in $\mathrm{Na}^{+}$concentration is strongly correlated with elevated sperm production and plasma t-GTH, suggesting hormonal regulation.

Symposium sur la Reproduction des Poissons Paimpont, France, 19-21 septembre 1977.

Acknowledgements. - This work was supported by a grant from the CNEXO (No 161977). Thanks are due to Dr. Gueguen, Station de Recherches de Nutrition, I. N. R. A., for providing the equipment for ion measurements and giving us advice on it.

Résumé. Une étude réalisée durant la période de spermiation chez la truite Arc-en-ciel a porté sur les taux plasmatiques de $t-G T H$ et d'androgènes immunoréactifs sur la production de sperme et les changements dans la composition du liquide séminal. Le volume de sperme recueilli après massage abdominal est très faible au début $(0,1 \mu l)$, augmente très légèrement au cours des quatre premières semaines et très fortement ensuite. Les teneurs plasmatiques en t-GTH sont élevées lorsque débute la spermiation et diminuent ensuite. La forte augmentation de production de sperme débute lorsque les teneurs en androgènes circulants ont atteint leur valeur maximum. Dans une seconde phase (6-12 semaines) l'augmentation de production de sperme est fortement corrélée avec les teneurs en t-GTH tandis que les niveaux d'androgènes fluctuent (fig. 1). La concentration du sperme en spermatozoïdes (spermatocrite) ne varie pas significativement pendant la période d'observation, de sorte que l'augmentation de production de sperme correspond à une augmentation de la production de spermatozoïdes (fig. 2). Pendant la période de 
spermiation la teneur du plasma séminal augmente fortement dans le cas de $\mathrm{Na}^{+}$et légèrement dans le cas de $\mathrm{K}+$. Par contre la teneur en protéines totales diminue significativement après la $8^{\mathrm{e}}$ semaine.

\section{References}

BILLARD R., 1974. Testosterone : effects on the maintenance of spermatogenesis in intact and hypophysectomized Goldfish (Carassius auratus). IRCS, 2, 1231.

BRETON B., JALABERT B., FOSTIER A., BILLARD R., 1975. Etude sur le cycle reproducteur de la truite Arc-en-ciel et de la tanche. J. Physiol., 70, 561-564.

CLEMENS H. P., GRANT F. B., 1965. The seminal thinning response of carp (Cyprinus carpio) and rainbow trout (Salmo gairdneri) after injection of pituitary extracts. Copeia, 2, 174-177.

CHEMAYEL M., 1975. Elude de la variabilité du pouvoir fécondant du sperme en relation avec ses caractéristiques chez la truite Arc-en-ciel Salmo gairdneri. Thèse $3^{\text {e }}$ Cycle, Univ. Paris VI, 52 pp.

CRIM L. W., WATTS E. G., EVANS D. M., 1975. The plasma gonadotropin profile during sexual maturation in a variety of salmo fishes. Gen. comp. Endocr., 27, 62-70.

HARTREE E. E., 1972. Determination of protein : a modification of the Lowry method that gives a linear photometric response. Analyt. Biochem., 48, 422-427.

IDLER D. R., HORNE D. A., SANGALANG G. B., 1971. Identification and quantification of the major androgens in the testicular and peripheral plasma of Atlantic salmon (Salmo salar) during sexual maturation. Gen. comp. Endocr., 16, 257-267.

SCHRECK C. B., LACKEY R. T., HOPWOOD M. L., 1972. Evaluation of diel variation in androgen levels of rainbow trout Salmo gairdneri. Copeia, 4, 865-868.

YAMAZAKI F., DONALDSON E., 1968. Involvement of gonadotropin and steroid hormones in the spermiation of the goldfish (Carassius auratus). Gen. comp. Endocr., 12, 491-497. 